\title{
Polyurethane Structures Used as a Drug Carrier for Epigallocatechin Gallate
}

\author{
AUREL MARIN ${ }^{1}$, MARIA ALINA MARIN ${ }^{2 *}$, IOAN ENE ${ }^{3}$, MARIOARA POENARU ${ }^{4}$ \\ 1"Victor Babes" University of Medicine and Farmacy, General Medicine, ENT Department, 2 Eftimie Murgu Sq, 300041, \\ Timisoara, Romania \\ 2"Victor Babes" University of Medicine and Farmacy, General Medicine, ENT Department, 2 Eftimie Murgu Sq, 300041, \\ Timisoara, Romania \\ ${ }^{3}$ Emergency Pediatric Hospital, ENT Department, 68 Motilor Str, 400001, Cluj Napoca, Romania \\ 4"Victor Babes" University of Medicine and Farmacy, General Medicine, ENT Department, 2 Eftimie Murgu Sq, 300041, \\ Timisoara, Romania
}

\begin{abstract}
The current study was proposed in order to obtain, to characterize by usually physicochemical methods and to assess in vitro, the potential cytotoxic effect of polyurethane microstructures loaded with epigallocatechin gallate (PU_MS) on human pharyngeal carcinoma cells (Detroit 562) and squamous cell carcinoma (SCC-4). The results showed that polyurethane microstructures obtained are stable and have dimensions that make them biocompatible with the biological environment. The cytotoxicity of test samples is dependent on concentration and $72 \mathrm{~h}$ after stimulation at the highest concentration tested the viability of tumor cells was below 50\%, the decrease being much more pronounced in the case of squamous cell carcinoma. The novel nanostructures loaded with epigallocatechin gallate induced an augmented cytotoxic effect, suggesting that this drug carriers are suitable to enhance the antitumor effect of epigallocatechin gallate.
\end{abstract}

Keywords: drug transporter, polyurethane strucrures, thermal degradation, cell viability, carcinoma cells

\section{Introduction}

The discovery of active molecules against cancer has grown in the last decade. Despite all the efforts made, the affected population is increasing and the survival rate in the case of patients varies greatly depending on the type of cancer, stage, age, country, etc. In general, the survival rate in developed countries is significantly higher compared to poorly developed or developing countries. Compounds from natural sources are an alternative used effectively in the study of anticancer drugs. The most relevant examples of anticancer drugs obtained from natural sources are given by Paclitaxel, vincristine and doxorubicin [1-3]. Despite the efforts, obtaining medicines from natural sources is not an easy one and depends on a series of factors such as: correct selection of isolation and separation methods, the influence of yield, evaluation method, legislation in force, etc.

The major chemical compounds of tea are represented by the class of catechins composed of a benzopyran backbone substituted with a phenyl (position 2) and hydroxyl or ester groups (position 3), respectively [4,5]. Polyphenols identified in green tea have been studied for years due to their influence on several important biological pathways and also the anticarcinogenic effects they show. Most of these effects are mainly attributed to the most abundant chemical compound (-) - EGCG (Figure 1).

Polyurethane materials have a long history since Prof. Bayer and his research team have developed the first foams in their laboratory from Leverkusen, Germany, more than 80 years ago; the first medical applications have been developed by Pangman in 1958 (a composite breast prostheses covered with a polyester-urethane foam) and in the same year, Mandarino and Salvatore have obtained a rigid polyurethane foam used for in situ bone fixation $\left(\right.$ Ostamer $\left.^{\mathrm{TM}}\right)$ [6,7]. The possibility to use polyurethanes as drug delivery systems was first described by Levy in 1988 when he has presented the obtaining of a poly(ether urethane) carrier used for the controlled release of lidocaine to normalize the cardiac rhythm; later, Hafeman has discovered another carrier used for a sustained release of tobramycin, Moura has

\footnotetext{
*email:alinamaria.muntean@yahoo.com
} 


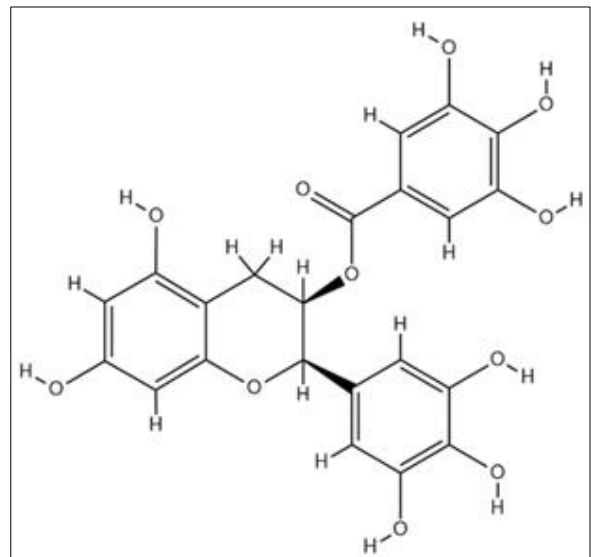

Figure 1. Chemical structure of Epigallocatechin gallate

reported the synthesis of dexamethasone-loaded polyurethane matrices etc. [8,9]. The advantages of these carriers are the following: a reduced cost of the raw materials, the possibility to modify the degradation period of macromolecular chains by balancing the ratio between the ether- and ester-polyols used in the aqueous phase, and the possibility to modify the size of particles by the use of different amounts of chain extenders (diols and diamines with low molecular weight) $[10,11]$.

The aim of the current study was to obtain polyurethane structures loaded with epigallocatechin gallate and to realize a preliminary evaluation of the compounds obtained on pharyngeal carcinoma cells and squamous cell carcinoma.

\section{Materials and methods}

\subsection{The reagents}

The raw materials used in the synthesis of the polyurethane microstructures (PU_MS) are: monoethylene-glycol (MEG) from Lach-Ner s.r.o. (Czech Rep.), 1,4-butanediol (BD) from Carl Roth $\mathrm{GmbH}$ (Germany), the solvent of the organic phase (acetone) from Chimopar S.A. (Romania), while the others: polyethylene glycol (PEG, average mol wt 200), the surfactant (Tween ${ }^{\circledR} 20$ ), isophoronediisocyanate (IPDI), and hexamethylene-diisocyanate (HMDI) were obtained from Merck (Germany) and epigallocatechin gallate (EGCG) was obtained from Sigma-Aldrich (Germany). All substances, high-purity reagents, were maintained under the conditions specified by the manufacturer and they were used as received, without any previous purification.

Inorganic salts of $\mathrm{Na}$ and $\mathrm{K}$, such as chlorides, mono- and diphosphates, $\mathrm{NaHCO}_{3}$, and $\mathrm{HCl}$ from Chimopar S.A. (Romania) were used to obtain a simulated body fluid (SBF) which is described in the literature $[12,13]$ as a proper medium to study the degradation of an organic drug delivery system and its release profile. They were previously heated at $110^{\circ} \mathrm{C}$ for $90 \mathrm{~min}$ in order to remove the crystallization water.

\subsection{The chemical synthesis}

A protocol based on five steps was used to synthesize PU_MS according to previous papers [11,1416]: (i) A non-aqueous phase based on a mixture of IPDI and HMDI in acetone (Table 1) was prepared under magnetic stirring ( $450 \mathrm{rpm}$ ) at $35^{\circ} \mathrm{C}$ for $15 \mathrm{~min}$; (ii) A hydroxylic phase based on a mixture of MEG, BD, PEG, and Tween ${ }^{\circledR} 20$ in deionized water was homogenized $(450 \mathrm{rpm})$ at $35^{\circ} \mathrm{C}$ for $10 \mathrm{~min}$; (iii) The organic phase was rapidly injected in the aqueous phase $(1: 1.4, \mathrm{v} / \mathrm{v})$ under magnetic stirring (550 rpm) at $40^{\circ} \mathrm{C}$ and the stirring continued for $5 \mathrm{~h}$ to ensure the maturation of the PU_MS macromolecular chains; (iv) The obtained suspensions were purified by repeated washing - slight centrifugations using a water-acetone mixture $(1: 1.2, \mathrm{v} / \mathrm{v}) ;(\mathrm{v})$ The products were dried as thin layers in Petri dishes at $65^{\circ} \mathrm{C}$ for more than $24 \mathrm{~h}$. 
The experiment was repeated three times to synthesize different samples for further comparative characterizations: PU_MS_0 (structures without EGCG), PU_MS_1 (structures with low amount of EGCG), and PU_MS_2 (structures with high amount of EGCG).

Table 1. The ratios between the raw materials.

\begin{tabular}{|c|c|c|c|c|c|c|c|}
\hline \multirow{2}{*}{ Sample } & \multicolumn{4}{|c|}{$\begin{array}{c}\text { Aqueous phase } \\
\text { (mL / 50 mL) }\end{array}$} & \multirow{2}{*}{$\begin{array}{c}\text { EGCG (mg / } \\
\text { 50 mL) }\end{array}$} & $\begin{array}{c}\text { Organic phase (mL / 50 } \\
\text { mL) }\end{array}$ \\
\cline { 2 - 4 } \cline { 7 - 8 } & MEG & BD & PEG & Tween & & IPDI & HMDI \\
\hline PU_MS_0 & 0.40 & 0.60 & 2.15 & 1.50 & 0.00 & 1.85 & 3.15 \\
\hline PU_MS_1 & 0.40 & 0.60 & 2.15 & 1.50 & 5.50 & 1.85 & 3.15 \\
\hline PU_MS_2 & 0.40 & 0.60 & 2.15 & 1.50 & 11.00 & 1.85 & 3.15 \\
\hline
\end{tabular}

\subsection{Characterization of the samples}

The efficacy of the drugs encapsulation can be calculated by reporting the untrapped active substances to the total amount that was added in that synthesis according to an old study on a polyurethane drug delivery system [17]. UV spectrometry using an UVi Line 9400 Spectrophotometer (SI Analytics, Germany) based on the difference between the maximum absorption (276 nm for EGCG and $353 \mathrm{~nm}$ for PU_MS_0), a calibration curve and the Beer-Lambert law were involved to establish the encapsulation efficacy. The release kinetics was determined by maintaining the samples PU_MS_1 and PU_MS_2 in a degradation medium, SBF from the recipe of T. Kokubo, much more proper to be used in different assessment based on the degradation of biomaterials [18,19] for ten days; 3 aliquots of each $0.2 \mathrm{~mL}$ medium were replaced every second day with fresh medium and their UV absorption was read at $276 \mathrm{~nm}$; average values $+/$ - standard errors were used to present the release profile [20].

The electric charge of PU_MS surface and their average size were evaluated using a Vasco Particle Size Analyzer and a Wallis Zeta potential Analyzer (both from Cordouan Technology, France); the following parameters were set: assessment temperature $\left(25 \pm 1^{\circ} \mathrm{C}\right)$, interval of time $(15 \pm 3 \mu \mathrm{s})$, number of channels (around 435), power of laser (75-90 \%), acquisition mode (continuous), analysis mode (PadeLaplace), Wallis resolution (medium), and Smoluchowski model as Henry function.

The thermal behavior of PU_MS was studied using a Mettler-Toledo DSC1 instrument (MettlerToledo, Switzerland) and aluminum crucibles with perforated lids, between $40-280^{\circ} \mathrm{C}$ in an inert atmosphere $\left(10^{\circ} \mathrm{C} / \mathrm{min}\right)$.

\subsection{In vitro evaluation of the samples}

The cells employed in the current experimental study were: pharyngeal carcinoma cells (Detroit 562: ATCC $®$ CCL-138 ${ }^{\mathrm{TM}}$ ) and squamous cell carcinoma (SCC-4: ATCC ${ }^{\circ}$ CRL-1624 ${ }^{\mathrm{TM}}$ ) acquired as frozen items from ATTC and stored in liquid $\mathrm{N}_{2}$ until the experimental use. The specific reagents required for cell culture were: EMEM and FBS 10\% for pharyngeal carcinoma cells and DMEM:F12 (contains Lglutamine, HEPES, sodium pyruvate, and sodium bicarbonate.), hydrocortisone and FBS $10 \%$ for squamous cell carcinoma were provided from ATTC. The cell culture with a confluence of minimum $80 \%$ was obtained according to manufacturer's specifications [21,22]

The analysis of cell viability was assessed by the means of MTT assay after $72 \mathrm{~h}$ post-treatment with different concentrations of test samples [23,24]. In short, 10,000 cells/well were seeded in a 96/well plate, after $24 \mathrm{~h}$ cell media was remote and the cells were stimulated with test samples; blank or control cells were stimulated only with specific media; cell viability was obtained after the plates were spectrophotometrically analyzed at $570 \mathrm{~nm}$ wavelength, with a microplate reader.

\section{Results and discussions}

\subsection{The encapsulation efficacy and the release kinetics}

A calibration curve between 0.05 and $2.50 \mu \mathrm{g} / \mathrm{mL}$ EGCG $(\mathrm{y}=0.42 \mathrm{x}-0.01 ; \mathrm{r}=0.9981)$ was used to calculate the encapsulation efficacy and the drug release. The relation between the level of the maximum adsorption and EGCG concentration (the Beer-Lambert law) indicates high encapsulation efficacy (62.93 
for PU_MS_1 and 77.18 for PU_MS_2). Polyurethane carriers, based on hollow nano- and microparticles, have a very good capacity to encapsulate large amounts of active substances: $67.9 \%$ was found in the case of a chili pepper extract [11] and $82.9 \%$ for a ginger extract [16].

Figure 2 presents the EGCG release inside the degradation media for the two samples of polyurethane microstructures containing different amounts of EGCG.

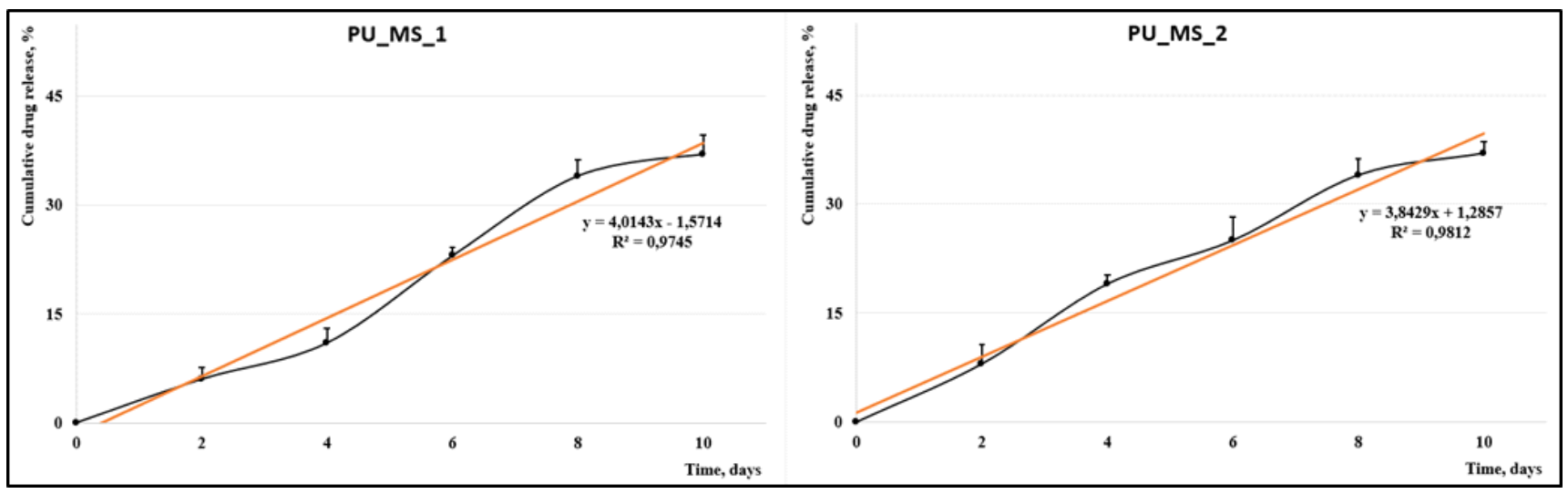

Figure 2. The release profile for EGCG from samples of PU_MS with active substance

The drug release depends on the degradation of the carrier macromolecules. Computational models play a key-role in the description of the release profiles; the trend of these PU_MS release can be described by the Equation 1 and 2. No important difference is described by these two equations; the cumulative drug release is around $37 \%$ for both samples after 10 days, but a slight increased value was determined in the fourth day in the case of the sample with an increased amount of EGCG used in the synthesis.

$$
\begin{aligned}
& y=4.0143 x-1.5714(R 2=0.9745) \\
& y=3.8426 x-1.2857(R 2=0.9812)
\end{aligned}
$$

The causes of transport phenomena are imbalances inside many systems or between the parts of different systems. The natural evolution is towards the uniformity of the properties, characterized by physical parameters that are constant in time and space. The drug release at a specific target is based on a transport process and taking into account that molecules have a mass, this process can be described by the Fick law about the mass diffusion - the mass flux $\left(J_{m}\right)$ is proportional to the mass density gradient $\left(\rho_{m}\right)[25]$ according to Equation 3.

where $D_{m}$ is the coefficient of molar diffusion.

$$
J_{m}=-D_{m}
$$

Kakar and collaborators have described a more useful model for the drug release from polymeric systems [26]; they present the Korsmeyer peppas model based on the fact that the fraction of drug released has a constant rate if it is expressed as logarithm of percent of cumulative drug release in function of the logarithm of time ( $\log \% \mathrm{CDR}=\mathrm{f}(\log T i m e))$. In biomedical applications, taking into account drug release, these transport nanotypes are safe and can be used as intelligent drug delivery matrices for targeted delivery [27,28].

\subsection{Zetasizer characterization}

Table 2 presents the PU_MS characterization that was obtained during the Zetasizer assessment. The decreased values of the polydispersity index (PDI) indicate the obtaining of almost homogeneous samples, while the Zeta potential values show a medium tendency of these structures to form agglomerations according to Gallardo et al. [29]. 
Table 2. Experimental values of the Zetasizer characterization

\begin{tabular}{|c|c|c|c|}
\hline \multirow{2}{*}{ Sample } & \multicolumn{2}{|c|}{ Size of structures $(\mathbf{n m})$} & \multirow{2}{*}{ Zeta potential $(\mathbf{m V})$} \\
\cline { 2 - 4 } & Mean \pm SD & PDI & +29.12 \\
\hline PU_MS_0 & $174 \pm 15$ & 0.2 & +25.79 \\
\hline PU_MS_1 & $229 \pm 17$ & 0.4 & +24.91 \\
\hline PU_MS_2 & $232 \pm 21$ & 0.4 & \\
\hline
\end{tabular}

\subsection{The thermal stability}

The investigation on the thermal stability of samples were done comparatively between the samples of the polyurethane carrier with and without the active agent against its EGCG sample (Figure 3). The glass transitions of the polymer structures were not observed inside the studied range of temperature, but it can be seen that a slight degradation starts around $270^{\circ} \mathrm{C}$. No significant peaks can be noticed in the thermograms of PU samples; the absence of the drug's characteristic peak indicates the complete encapsulation inside the PU carrier [30].

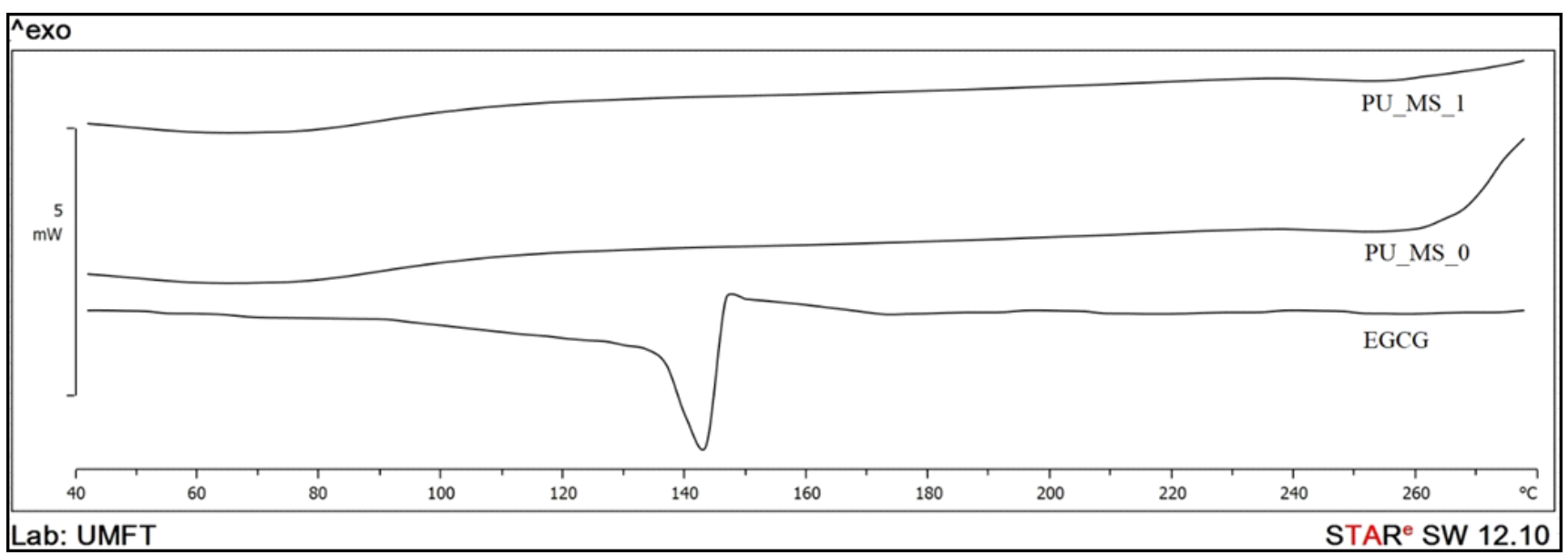

Figure 3. DSC thermograms of samples with and without drug vs. EGCG

The melting point of EGCG is between $140-142{ }^{\circ} \mathrm{C}$ and it was found during these analyses; on the other hand, the absence of this peak from the thermogram of sample PU_MS_1 confirmed the good encapsulation of the active compound.

\subsection{In vitro tests on tumoral cells}

A number of in vitro studies have shown that polyphenols in green tea or (-) - pure EGCG have influenced oral squamous cell carcinoma cells and other oral epithelial cells.

The cytotoxicity of test samples, was assessed on pharyngeal carcinoma cells (Detroit 562) and squamous cell carcinoma (SCC-4) by MTT colorimetric method. The evaluation was realized with various concentrations $(5,10,25$, and $50 \mu \mathrm{M})$ of samples after a stimulation time of $72 \mathrm{~h}$.

The data (Figure 4 and 5) indicated that test samples exerted different influences on cell viability. At low concentration $(5 \mu \mathrm{M})$ samples did not induced significant cell viability reduction. The lowest cell viability percentages were recorded after exposure of SCC-4 cells to $50 \mu \mathrm{M}$ of PU_MS_2( 21\%) and PU_MS_1 ( 21\%), followed by treatment of Detroit 562 cells with PU_MS_2 at concentration of 50 $\mu \mathrm{M}(\sim 50 \%)$, EGCG at concentration of $50 \mu \mathrm{M}(\sim 52 \%)$ and PU_MS_1 at concentration of $50 \mu \mathrm{M}(\sim 58 \%)$ as can be seen in Figures 4 and 5 . 

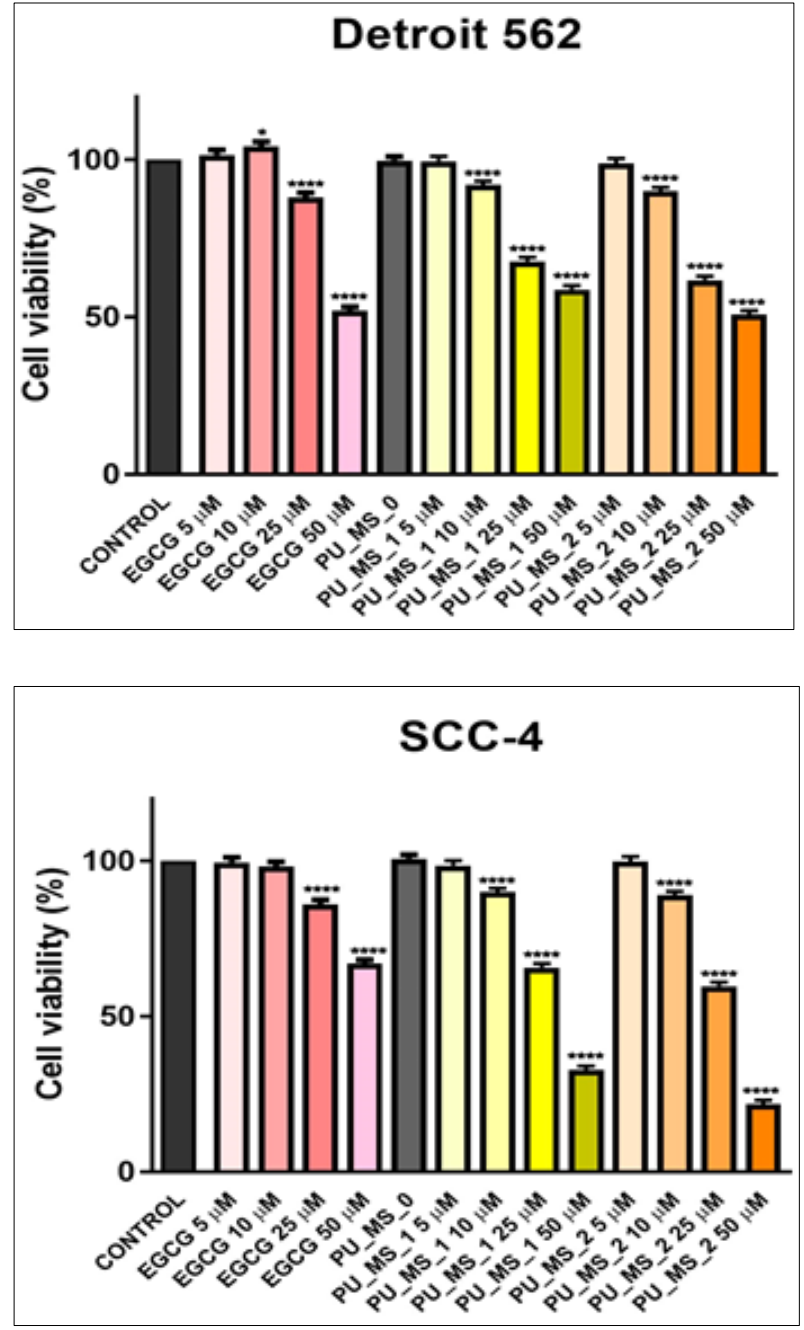

Figure 4. Viability percentage of pharyngeal carcinoma cells after stimulation with test samples $(5,10,25$ and $50 \mu \mathrm{M})$, at $72 \mathrm{~h}$ post-stimulation

Masuda et al. have highlighted that among the many bioactive molecules EGCG seems to be one of the most promising, especially due to its clinical efficacy but also the biological effects on certain lipid layers [31]. EGCG also has been shown to prevent the invasion and metastasis of the OC2 and SCC-9 cells by inhibiting MMP2 and MMP9 matrix metalloproteinase and suppressing urokinase plasminogen activator activity [32,33]. Another study conducted by Irimie et al. showed that EGCG can induce the activation of cell death receptors in the case of SCC-4 cells, suggesting the importance potential of the compunds as natural drug candidate [34].

\section{Conclusions}

The purpose of this study was achieved by the obtaining of a polyurethane drug delivery system used for the transmembrane transfer of Epigallocatechin gallate; the carrier consists of almost homogeneous particles with a high encapsulation efficacy, diameters around $200 \mathrm{~nm}$, with a medium tendency to form agglomerations, very stable during heating processes. Furthermore, the data obtained from cell viability evaluations indicated that polyurethane structures loaded with epigallocatechin gallate exerts a cytotoxic which deserves to be studied in more detail and in vivo studies.

\section{References}

1. CRAGG, G.M., GROTHAUS, P.G., NEWMAN, D.J., Impact of natural products on developing new anticancer agents. Chemical Reviews, 109, 2009, 3012-3043.

2. SECA, A.M.L., PINTO, D.C.G.A., Plant Secondary Metabolites as Anticancer Agents: Successes in Clinical Trials and Therapeutic Application. Int J Mol Sci, 19(1), 2018, 263. doi: 10.3390/ijms19010263. 
3. GEZICI, S., ŞEKEROĞLU, N., Current Perspectives in the Application of Medicinal Plants Against Cancer: Novel Therapeutic Agents. Anticancer Agents Med Chem., 19(1), 2019, 101-111.

doi: $10.2174 / 1871520619666181224121004$

4. CHEN, D., WAN, S.B., YANG, H., YUAN, J., CHAN, T.H., DOU, Q.P., EGCG, green tea polyphenols and their synthetic analogs and prodrugs for human cancer prevention and treatment. Adv. Clin. Chem. 53, 2011, 155-177.

5. KHAN, N., MUKHTAR, H., Tea Polyphenols in Promotion of Human Health. Nutrients. 11(1), 2018, 39. doi:10.3390/nu11010039.

6. WANG, W., WANG, C., Polyurethane for biomedical applications: A review of recent developments, in DAVIM, J.P. (Ed.) The Design and Manufacture of Medical Devices, Woodhead Publishing Reviews: Mechanical Engineering Series, 2012, 115-151.

7. GAMA, N.V., FERREIRA, A., BARROS-TIMMONS, A., Polyurethane Foams: Past, Present, and Future. Materials (Basel). 11(10), 2018, 1841. doi: 10.3390/ma11101841.

8. COOPER, S.L., GUAN, J., Advances in Polyurethane Biomaterials. Woodhead Publishing Series in Biomaterials, Elsevier, 2016, 405-407.

9. SAVELYEV, Y., VESELOV, V., MARKOVSKAYA, L., SAVELYEVA, O., AKHRANOVICH, E., GALATENKO, N., ROBOTA, L., TRAVINSKAYA, T., Preparation and characterization of new biologically active polyurethane foams. Mater Sci Eng C Mater Biol Appl. 45, 2014, 127-35.

doi: 10.1016/j.msec.2014.08.068.

10. MUNTEANU, M.F., ARDELEAN, A., BORCAN, F., TRIFUNSCHI, S.I., GLIGOR, R., ARDELEAN, S.A., CORICOVAC, D., PINZARU, I., ANDRICA, F., BORCAN, L.-C., Mistletoe and Garlic Extracts as Polyurethane Carriers - A Possible Remedy for Choroidal Melanoma. Curr. Drug Delivery, 14(8), 2017, 1178-1188.

11. BORCAN, L.C., DUDAS, Z., LEN, A., FUZI, J., BORCAN, F., TOMESCU, M.C. Synthesis and characterization of a polyurethane carrier used for a prolonged transmembrane transfer of a chili pepper extract. Int J Nanomed., 13, 2018, 7155-7166, doi: 10.2147/IJN.S181667.

12. ALBULESCU, R.C., BORCAN, F., PAUL, C., VELEA, I., PUIU, M., Development and in vitro evaluation of polyurethane microparticles as carrier for bevacizumab: an alternative treatment for retinopathy of prematurity. Int. Curr. Pharm. J., 3(6), 2014, 275-279.

13. NEGUT, I., FlOROIAN, L., RISTOSCU, C., MIHAILESCU, C.N., MIRZA ROSCA, J.C., TOZAR, T., BADEA, M., GRUMEZESCU, V., HAPENCIUC, C., MIHAILESCU, I.N., Functional Bioglass-Biopolymer Double Nanostructure for Natural Antimicrobial Drug Extracts Delivery. Nanomaterials (Basel), 10(2), 2020, 385.

14. HEGHES, A., SOICA, C.M., ARDELEAN, S., AMBRUS, R., MUNTEAN, D., GALUSCAN, A., DRAGOS, D., IONESCU, D., BORCAN, F., Influence of emulsifiers on the characteristics of polyurethane structures used as drug carrier. Chem. Cent. J., 7(1), 2013, 66.

15. DANCIU, C., BORCAN, F., ȘOICA, C., ZUPKO, I., CSANYI, E., AMBRUS, R., MUNTEAN, D., SASS, C., ANTAL, D., TOMA, C., DEHELEAN, C., Polyurethane Microstructures-a Good or Bad in vitro Partner for the Isoflavone Genistein? Nat. Prod. Comm., 10(6), 2015, 951-954.

16. BORCAN, F., CHIRITA-EMANDI, A., ANDREESCU, N.I., BORCAN, L.-C., ALBULESCU, R.C., PUIU, M., TOMESCU, M.C. Synthesis and preliminary characterization of polyurethane nanoparticles with ginger extract as a possible cardiovascular protector. Int. J. Nanomed., 14, 2019, 3691-3703.

17. BOUCHEMAL, K., BRIANCON, S., PERRIER, E., FESSI, H., BONNET, I., ZYDOWICZ, N. Synthesis and characterization of polyurethane and poly(ether urethane) nanocapsules using a new technique of interfacial polycondensation combined to spontaneous emulsification. Int. J. Pharm., 269, 2004, 89-100.

18. LEE, J.T., LENG, Y., CHOW, K.L., REN, F., GE, X., WANG, K., LU, X., Cell culture medium as an alternative to conventional simulated body fluid. Acta Biomater., 7(6), 2011, 2615-22.

doi: 10.1016/j.actbio.2011.02.034. 
19. LU, X., LENG, Y., Theoretical analysis of calcium phosphate precipitation in simulated body fluid. Biomaterials. 26(10), 2005, 1097-108. doi: 10.1016/j.biomaterials.2004.05.034.

20. QUAN, H., PARK, Y.K., KIM, S.K., HEO, S.J., KOAK, J.Y., HAN, J.S., LEE, J.H., Surface Characterization and Human Stem Cell Behaviors of Zirconia Implant Disks Biomimetic-Treated in Simulated Body Fluid. Int. J. Oral Maxillofac. Implant., 31, 2016, 928-938.

21. ***https://www.lgcstandards-atcc.org/products/all/CCL-138.aspx

22. ***https://www.lgcstandards-atcc.org/products/all/CRL-1624.aspx

23. CORINA, D., BOJIN, F., AMBRUS, R., MUNTEAN, D., SOICA, C., PAUNESCU, V., CRISTEA, M., PINZARU, I., DEHELEAN, C., Physico-chemical and Biological Evaluation of Flavonols: Fisetin, Quercetin and Kaempferol Alone and Incorporated in beta Cyclodextrins. Anticancer Agents Med Chem., 17(4), 2017, 615-626. doi: 10.2174/1871520616666160621105306.

24. ANDOR, B., DANCIU, C., ALEXA, E., ZUPKO, I., HOGEA, E., CIOCA, A., CORICOVAC, D., PINZARU, I., PĂTRAȘCU, J.M., MIOC, M., CRISTINA, R.T., SOICA, C., DEHELEAN, C., Germinated and Ungerminated Seeds Extract from Two Lupinus Species: Biological Compounds Characterization and In Vitro and In Vivo Evaluations. Evid.-Based Complementary Altern. Med., 2016, 2016, 7638542. doi:10.1155/2016/7638542.

25. SCARLAT, E., NICOLIN, A. [Fizica - Fenomene de transport. Curs]. Univ. “Al. I. Cuza” Iasi, 2015. 26. KAKAR, S., SINGH, R., SEMWAL, A. Drug release characteristics of dosage forms: a review. $J$. Coastal Life Med., 2, 2014, 332-336.

27. SHOAIB, M., BAHADUR, A., SAEED, A., RAHMAN, M.S.U., NASEER, M.M., Biocompatible, $\mathrm{pH}$-responsive, and biodegradable polyurethanes as smart anti-cancer drug delivery carriers. React. Funct. Polym., 127, 2018, 153. doi:10.1016/j.reactfunctpolym.2018.04.010;

28. NIU, Y., STADLER, F.J., SONG, J., CHEN, S., CHEN, S., Facile fabrication of polyurethane microcapsules carriers for tracing cellular internalization and intracellular $\mathrm{pH}$-triggered drug release. Colloids Surf B Biointerfaces. 153, 2017, 160-167. doi: 10.1016/j.colsurfb.2017.02.018.

29. GALLARDO, V., MORALES, M.E., RUIZ, M.A., DELGADO, A.V. An experimental investigation of the stability of ethylcellulose latex. Correlation between zeta potential and sedimentation. Eur. $J$. Pharm. Sci., 26, 2005, 170-175.

30. BORCAN, F., LEN, A., DEHELEAN, C.A., DUDÁS, Z., GHIULAI, R., IFTODE, A., RACOVICEANU, R., SOICA, C.M., Design and Assessment of a Polyurethane Carrier Used for the Transmembrane Transfer of Acyclovir. Nanomaterials (Basel). 11(1), 2020, 51. doi: 10.3390/nano11010051.

31. MASUDA, M., WAKASAKI, T., TOH, S., SHIMIZU, M., ADACHI, S., Chemoprevention of Head and Neck Cancer by Green Tea Extract: EGCG-The Role of EGFR Signaling and "Lipid Raft", Journal of Oncology, 2010, 2010, Article ID 540148, 7.

32. HARI, S., VASUDEVAN, V., KASIBHOTLA, S., REDDY, D., VENKATAPPA, M., DEVAIAH, D., Anti-inflammatory Dietary Supplements in the Chemoprevention of Oral Cancer, Cancer Research Frontiers. 2(3), 2016, 380-395

33. CHEN, P.N., CHU, S.C., KUO, W.H., CHOU, M.Y., LIN, J.K., HSIEH, Y.S., Epigallocatechin-3 Gallate Inhibits Invasion, Epithelial-Mesenchymal Transition, and Tumor Growth in Oral Cancer Cells, J. Agric. Food Chem., 59(8), 2011, 3836-3844.

34. IRIMIE, A.I., BRAICU, C., ZANOAGA, O., PILECZKI, V., GHERMAN, C., BERINDANNEAGOE, I., CAMPIAN, R.S., Epigallocatechin-3-gallate suppresses cell proliferation and promotes apoptosis and autophagy in oral cancer SSC-4 cells, Onco Targets Ther., 8, 2015, 461-470.

$\overline{\text { Manuscript received: } 11.05 .2020}$ 